\title{
Queen Hatshepsut and the Opet Festival
}

\author{
Samar Mostafa Kamal ${ }^{a}$ \\ Maged Abd El-Halim Radi ${ }^{\text {c }}$, \\ , Ebrahim Ali Mohammed ${ }^{\mathrm{b}}$, \\ a Professor of Egyptology, Faculty of Tourism and Hotels, Minia University \\ b Master Degree Researcher, Faculty of Tourism and Hotels, Minia University \\ c Lecturer of Tourist Guidance, Faculty of Tourism and Hotels, Minia University
}

\section{Keywords}

Opet festival Karnak Temple Luxor Temple Hatshepsut

\begin{abstract}
The annual Opet Festival, during which the sacred barks of the triad of Thebes, Amun, Mut, and Khonsu, together with that of the ruling king journeyed from Karnak to Luxor, became a central religious celebration of Thebes as early as the 18th Dynasty. The rituals of the Opet Festival celebrated the sacred marriage of god Amun, with whom the king merged, and goddess Mut, resulting in the proper transmission of the royal ka and thus ensuring the maintenance of kingship.

This paper will try to survey the Opet festival scenes which were depicted on the Theban monuments of queen Hatshepsut. The paper results will be based on iconographic material and descriptive methodology.
\end{abstract}




\section{Introduction}

The Opet festival was one of the most important festivals celebrated in ancient Egypt especially at Thebes. The festival had a religious and ritualistic meaning which definitely related to the king's royal ka. The Opet Festival was also held annually for Amon-re and the ruling king, for the renewal of his kingship. Additionally, it played a principal role in legitimating kingship (Murnane, W. 1986).

The name of the festival, $h b$ ipt, or $h b n f r n i p t$, "the beautiful feast of the Opet", relates to that of Luxor Temple, ipt-rsyt, which was perhaps referring to the inner most southern chapels at Luxor temple where the sacred marriage between god Amon and goddess Mut was held (Darnell, J. C., 2010).

The oldest survived Opet festival depictions dated back to the reign of queen Hatshepsut, $18^{\text {th }}$ Dynasty, (1490-1468 BC), New Kingdom. It seemed to be continued into the Roman period. The ancient textual Opet festival documentation was the massive inscription which was curved in sunk relief on the walls of the western wing of the third pylon at Karnak temple (Barguet, P., 1962).

The Opet festival was celebrated annually in the second month of the Akhet, inundation, season. During the $18^{\text {th }}$ Dynasty, the ceremonies of the festival lasted for only 11 days while in the reign of Ramses III, $19^{\text {th }}$ Dynasty, the festival extended to 24 days (Bell, L., 1985).

The earliest documented and most complete representations of the Opet festival were located on the Red Chapel of Hatshepsut at Karnak and her mortuary temple at Deir El-Bahary (Callender, V. G. 2002) . Tuthmosis III recorded his own scenes at the Ahk-memu at Karnak. Amenhotep III depicted the best preserved Opet festival textual evidence and scenes on the walls of the western wing of the third pylon at Karnak, in addition to the damaged scenes which were depicted in high relief on the western and eastern walls of his colonnade at Luxor temple (Bell, L., 1997) . These scenes were of the colonnade were reworked later by Tutankhamon and Horemoheb. ${ }^{1}$

During the $19^{\text {th }}$ Dynasty, New Kingdom, King Sety I depicted his own Opet festival scenes on the walls of the great hypostyle hall at Karnak. Ramses II also had scenes on the same hall in addition to the court between the $8^{\text {th }}$ and $9^{\text {th }}$ pylons at Karnak. Sety II depicted the common Opet festival scenes on the walls of the triple shrine he erected as a resting place for the sacred barks of the Theban triad during the celebration of the festival ceremonies. Ramses III also had other Opet festival scenes on the outer walls of his temple pylon at Karnak, and at his temple at Medinet Habu (Darnell, J.C., 1994).

\section{Discussion}

The earliest remaining and best-preserved scenes were that of queen Hatshepsut on the walls of the red chapel at Karnak (Accetta, K., 2012) . Hatshepsut was one of the most debated characters of ancient Egyptian history. Her masculine iconography, her famous conflict with Tuthmosis III, her accession to the throne and the story of her divine birth. All these issues were among the endless discussion regarding the queen (Galán, J.M., et.al, 2010) . Hatshepsut was the fifth ruler of the $18^{\text {th }}$ Dynasty. Hatshepsut was the daughter and only child of Thutmose I and his

${ }^{1}$ Ibid. 
primary wife, Ahmose. Her husband Thutmosis II was the son of Thutmosis I. Hatshepsut and Thutmosis II had a daughter named Neferure. Thutmosis II with Iset, a secondary wife, had their son Thutmosis III, who would succeed Hatshepsut on the throne (Roehrig, C., et.al, 2005).

The oldest surviving scenes of the Opet Festival related to queen Hatshepsut. This was illustrated on the walls of her red chapel at Karnak temple and her mortuary temple at Deir El-Bahary. These scenes reveal the transportation of the bark of Amun from Karnak along a land route to Luxor, then returned to Karnak by Nile. The procession was accompanied by priests, singers, dancers and acrobats. Then the boat was resting at six bark shrines on the way to Luxor, Amun's bark then returned to Karnak by water (Cabrol, A., 1999).

Some scholars suggested that the journey of the sacred boat of god Amon regarding the Opet festival ceremony resembled the night journey of god $\operatorname{Re}$ represented in the Amduat (Mironova, A.V., 2010).

\section{The Scenes}

The earliest and one of the most informative series of the Opet festival scenes appears on the south side of the red chapel of queen Hatshepsut at Karnak. A relief on the outer South wall of the red chapel of Queen Hatshepsut at Karnak, block no. 226, (Figure 1) (Qumsan, M., 2020) . This scene was a part of the land road journey of the god's procession from Karnak to Luxor. Queen Hatshepsut was burning incense in front of the sacred boat of god Amon leaving Karnak temple. The boat was carried on the shoulder of a group of clean-shaven priests. The boat was ended in both sides by the ram heads looking ahead, traditional symbol, of god Amon with twisted horns and the wsh collar around the neck.

Another relief on the outer South wall of the red chapel of Queen Hatshepsut at Karnak, block no. 300, shows Amon's boat was then settled on the first resting place in the chapel, while queen Hatshepsut was standing next to the chapel carrying incense pots with both hand ${ }^{2}$, The performance of burning incense before god Amon's boat was depicted on Figures (2 and 5). The boat was flanked by two Osorian statues of the queen; one was wearing the white crown of Upper Egypt while the other was wearing the double crown of Upper and Lower Egypt (Figures 2, 5).

The carried boat of god Amon was then leaving the first resting place at Karnak, while Queen Hatshepsut was accompanied this time with Tuthmosis III (Figure 3).

The sacred boat of God Amon was then being held on the priests' shoulders leaving the second resting place at Karnak. This scene was illustrated on the outer South wall of the red chapel of Queen Hatshepsut at Karnak, block no. 305 (Figure 4) (Darnell, J. C., 2010).

In the processional way back sailing from Luxor to Karnak, Amon's boat wsr$h^{3} t$ was depicted in the presence of Hatshepsut and Tuthmosis III (Figure 6). The boat

\footnotetext{
2 The ancient Egyptians used incense in many aspects of their daily lives. Incense was also considered in the ritualistic performances, burning incense was of major importance in the daily service of cult temples. It was used in almost every ritual taking place inside Egyptian temples for the sake of protecting and eternal purposes. Pritchard, J.B., 2016, "Egyptian Rituals and Incantations: ". Ancient Near Eastern Texts Relating to the Old Testament with Supplement, edited by James B. Pritchard, Princeton: Princeton University Press, p. 325-330. https://doi.org/10.1515/9781400882762-016
} 
was terminated on both sides by a ram head, the sacred symbol of god Amon, with upright serpent on the head and the wsh collar on the neck. Additional protective motifs were presented such as the jackal and the crowned sphinx. A naos with a semiarched roof in the middle of the boat is decorated with four rows of hieroglyphic signs, $d d$ and tit, symbols of protection, resurrection and rebirth. Hatshepsut and Tuthmosis III were depicted performing the beginning of the sailing rituals. Hatshepsut was standing to the right side before the naos, wearing the hprš crown and $w s h$ collar, and in front of her a vertical line of inscription reads; $d w^{3} n \underline{t} \underline{r}$ Imn- $R$ r $s p$ $f d w$, "Adoring God Amon-Re four times". Tuthmosis III was standing to the left side behind the naos while rowing by the oar, and in front of him a vertical line of inscription reads; hnt sp $f d w$, "Rowing four times". 3

Another characteristic ritual was also performed by Hatshepsut who was running and accompanied by the Apis bull aside wsr-h $h^{3} t$ boat of god Amon, while resting on his own shrine, block no. 102, south wall, the red chapel at Karnak temple (Figure 7).

The Apis bull, from earliest times, had been associated with the king and monarchial power, and so the Apis bull would walk beside the king as a show of divine approval. In certain ancient Egyptian festival ceremonies such as the Opet, the Apis bull would remain in the king's presence as a continual presentation of power and souverain.

Hatshepsut was depicted offering the wsh collar to the sacred boat of god Amon. This was occurred two times, the first scene was partly damaged especially the figure of the queen, block no. 99 on the south wall in the holy of holies of the red chapel at Karnak. The other scene is in a good condition, block no. 31 on the north wall in the holy of holies of the red chapel at Karnak (Figure 8).4 This ritualistic performance was an important part of the gods' festival ceremonies as early as the 18th Dynasty (Karlshausen, C., 1995).

\section{Opet Festival Scenes at Deir El-Bahari}

Very few scenes were remained from the Opet festival procession from Karnak to Hatshepsut's memorial temple at Deir el-Bahari and their way back to Karnak. Among the rare scenes, (Figure 9), a partly destroyed scene of the Nile journey of Amon's boat at Deir el-Bahari.

\footnotetext{
${ }^{3}$ The ritual of rowing four times was one of the most important rituals of the Opet festival ceremonies which was performed by the ruling king and most probably was just a symbolic ritual. Lacau, P. and Chevrier, H., 1977, Une chapelle d'Hatshepsout à Karnak. 2 volumes (1977 - 1979). Cairo, Institut français d'archéologie orientale du Caire, p. 180.

4 The wsh collars were offered as protective motifs to deities especially on the wall scenes of cult temples, and occasionally this was a part of the everyday ritual regarding the dressing of gods' statues. Aldred, C., 1971, Jewels of the Pharaohs. Egyptian Jewelry of the Dynastic Period, New York, Praeger Publishers; Handoussa, T., 1981, "Le Collier Ousekh". SAK 9, Hamburg, p. 143-150; Auth, S.H., 2003, "Beads and other Ornaments. Mosaic Glass Necklaces from Ptolemaic Egypt: Gifts for Deities and the Deceased". Annales du 16e CongrÂ"sẦ de L'association Internationale pour L'Histoire du Verre (AIHV), p. 315-319.
} 


\section{Figures}

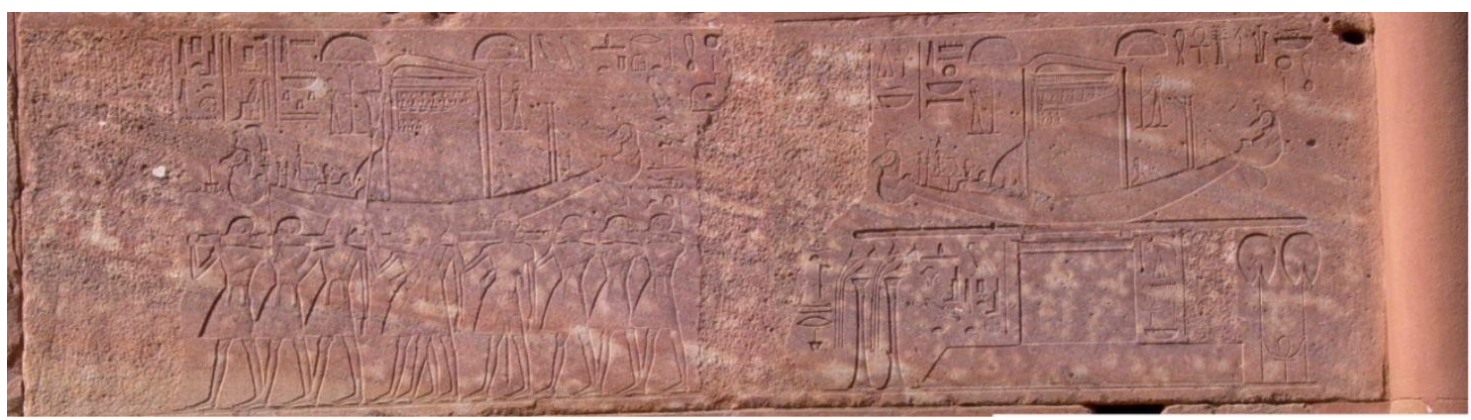

Figure 1: A relief on the outer South wall of the red chapel of Queen Hatshepsut at Karnak, block no. 226, 18th Dynasty, New Kingdom.

Source: Qumsan, M., 2020, "Amon Weserhat" The sacred Boat of God Amon in the Ancient Egyptian Sources. An Archaeological Study, An Unpublished Master Degree Thesis, Faculty of Arts, Asiut Uni., Figure 31-1, p. 74.

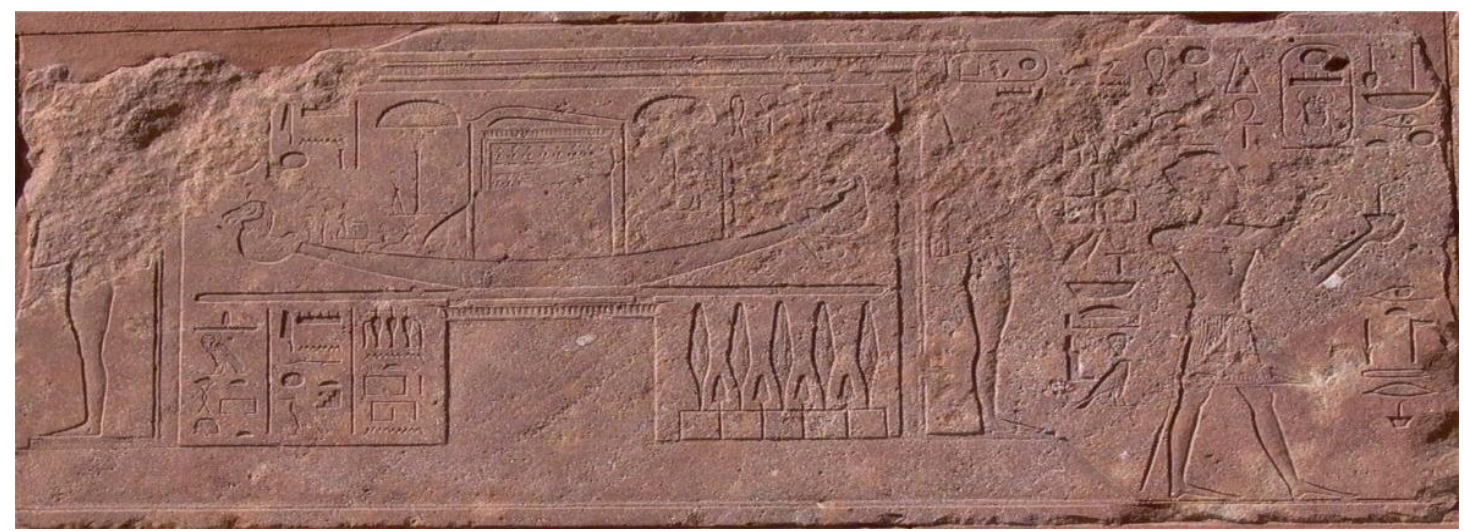

Figure 2: A relief on the outer South wall of the red chapel of Queen Hatshepsut at Karnak, block no. 300, 18th Dynasty, New Kingdom.

Source: Qumsan, M., "Amon Weserhat", 2020, Ibid, Figure 31-2, p. 75

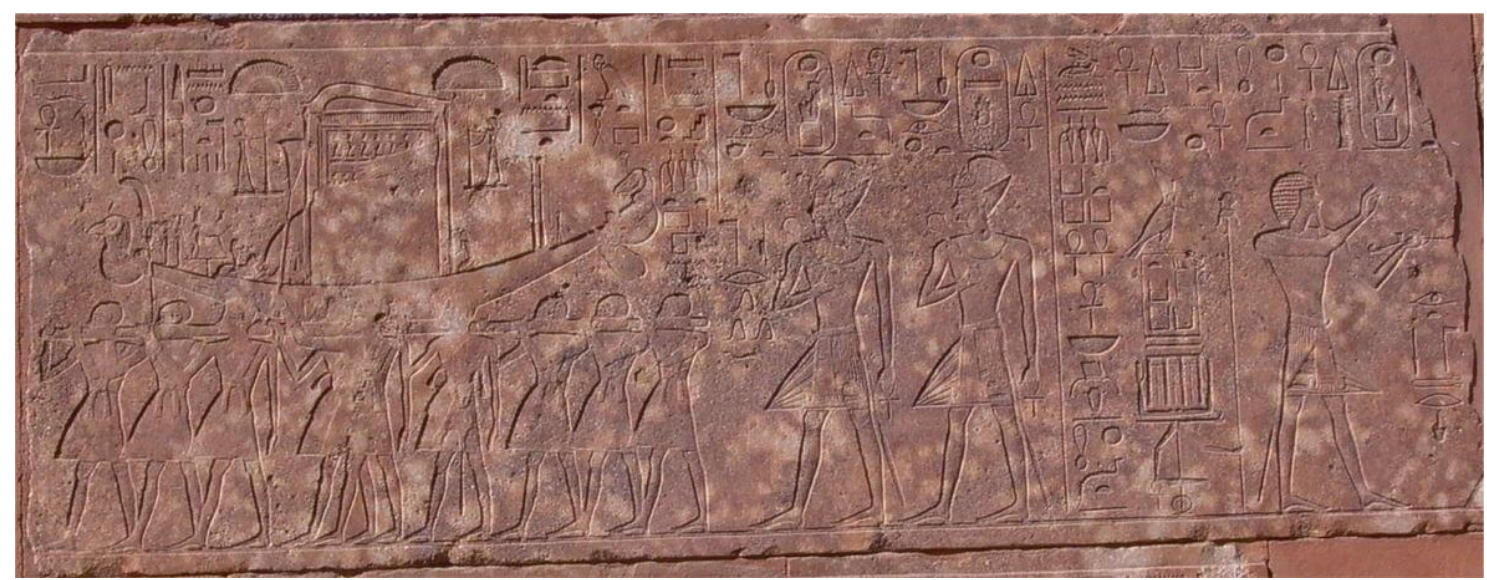

Figure 3: A relief on the outer South wall of the red chapel of Queen Hatshepsut at Karnak, block no. 26, 18th Dynasty, New Kingdom.

Source: Ibid, Figure 31-3, p. 75 


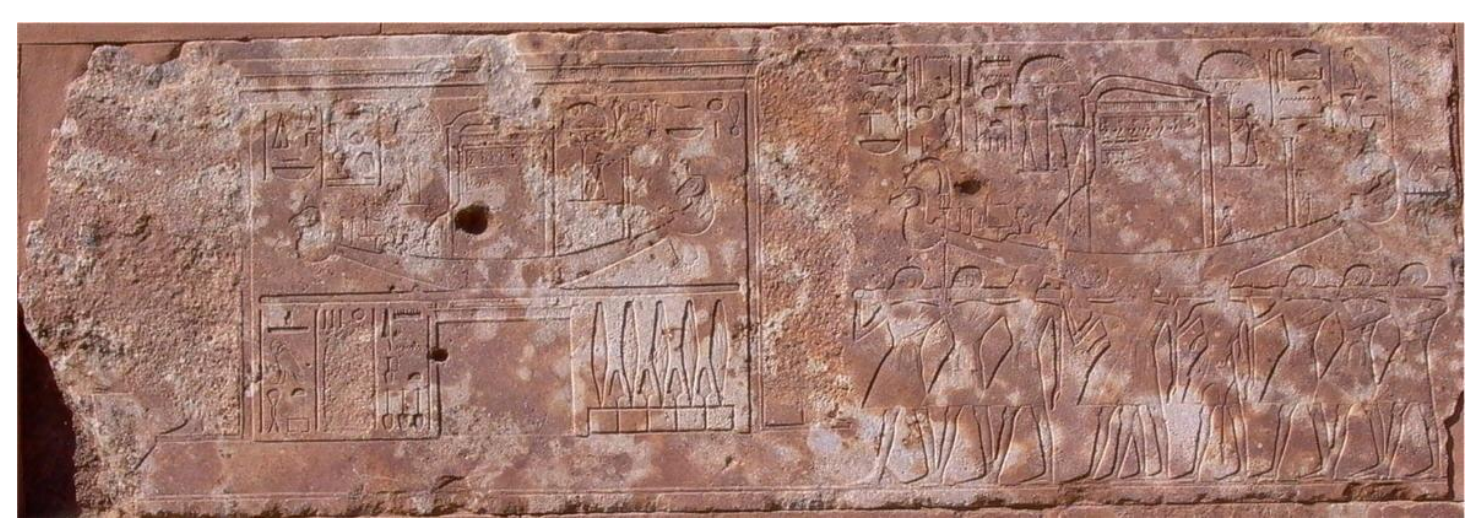

Figure 4: The sacred boat of God Amon is being held on the priests' shoulders, on the outer South wall of the red chapel of Queen Hatshepsut at Karnak, block no. 305, 18th Dynasty, New Kingdom.

Source: Darnell, J. C., 2010, Opet Festival. Jacco Dieleman, Willeke Wendrich (eds.), UCLA Encyclopedia of Egyptology, Los Angeles.

http://digital2.library.ucla.edu/viewItem.do?ark=21198/zz0025n765, p.1-15, Figure 1.

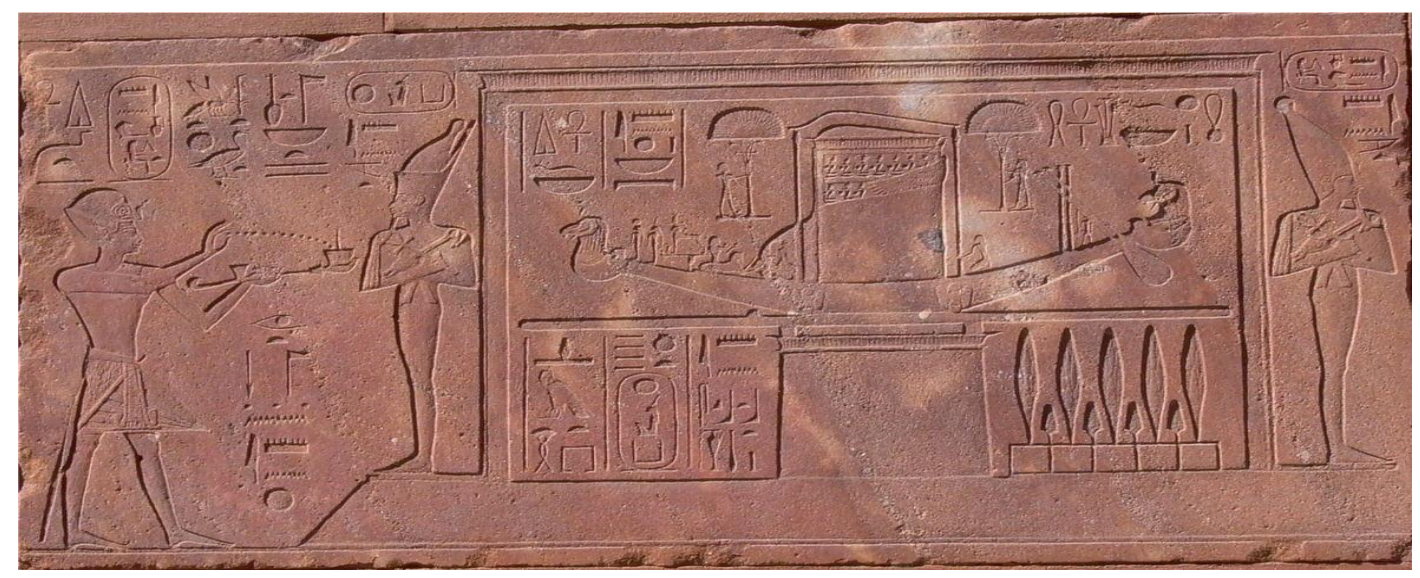

Figure 5: Queen Hatshepsut is burning incense before the boat of God Amon, while his boat is resting on the rest place, block no. 135, south wall, and the red chapel at Karnak temple.

Source: Mironova, A.V., 2010, "The Relationship between the Space and the Scenery of an Egyptian Temple: Scenes of the Opet Festival and the Festival of Hathor at Karnak and Deir el-Bahari under Hatshepsut and Thutmose III", MOSAIK journal 1, 2010, p. 279-330, Fig. 5. 


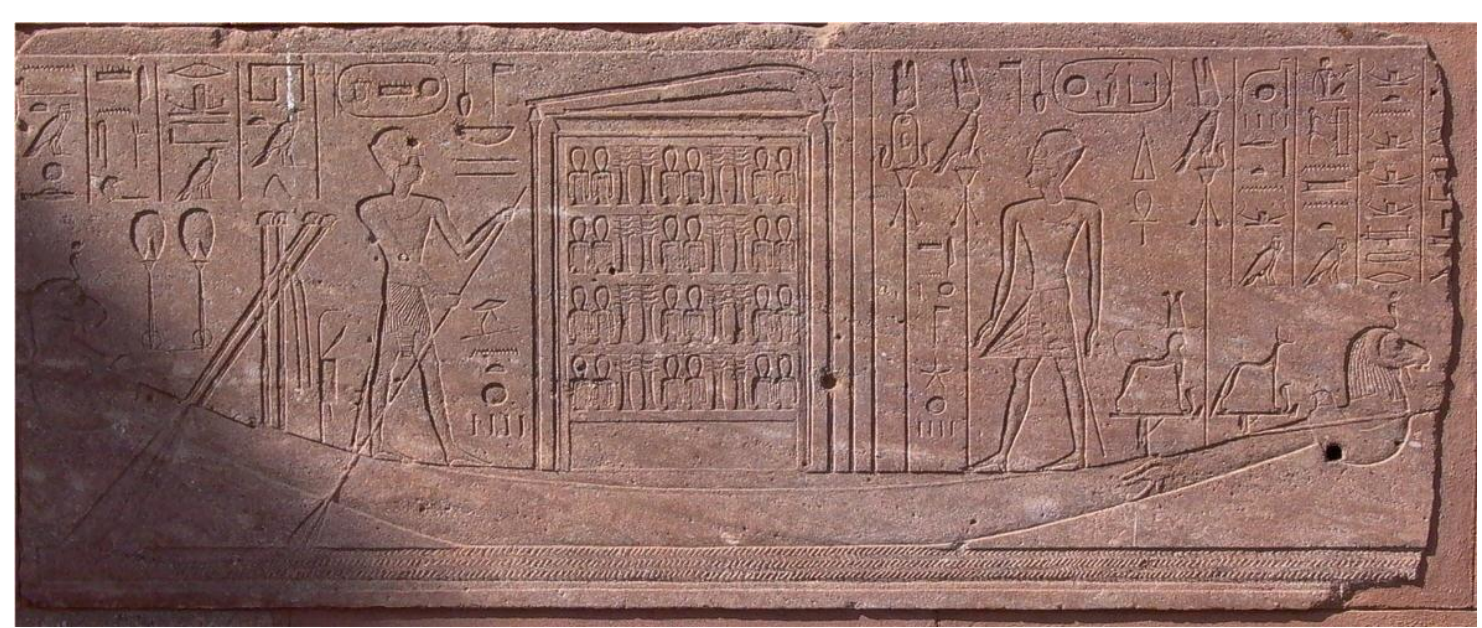

Figure 6: Queen Hatshepsut is flanking the central naos on the weser-hist boat, block no. 104, south wall, the red chapel at Karnak temple.

Source: Qumsan, M., “Amon Weserhat", 2020, Figure 31-8, p. 77.

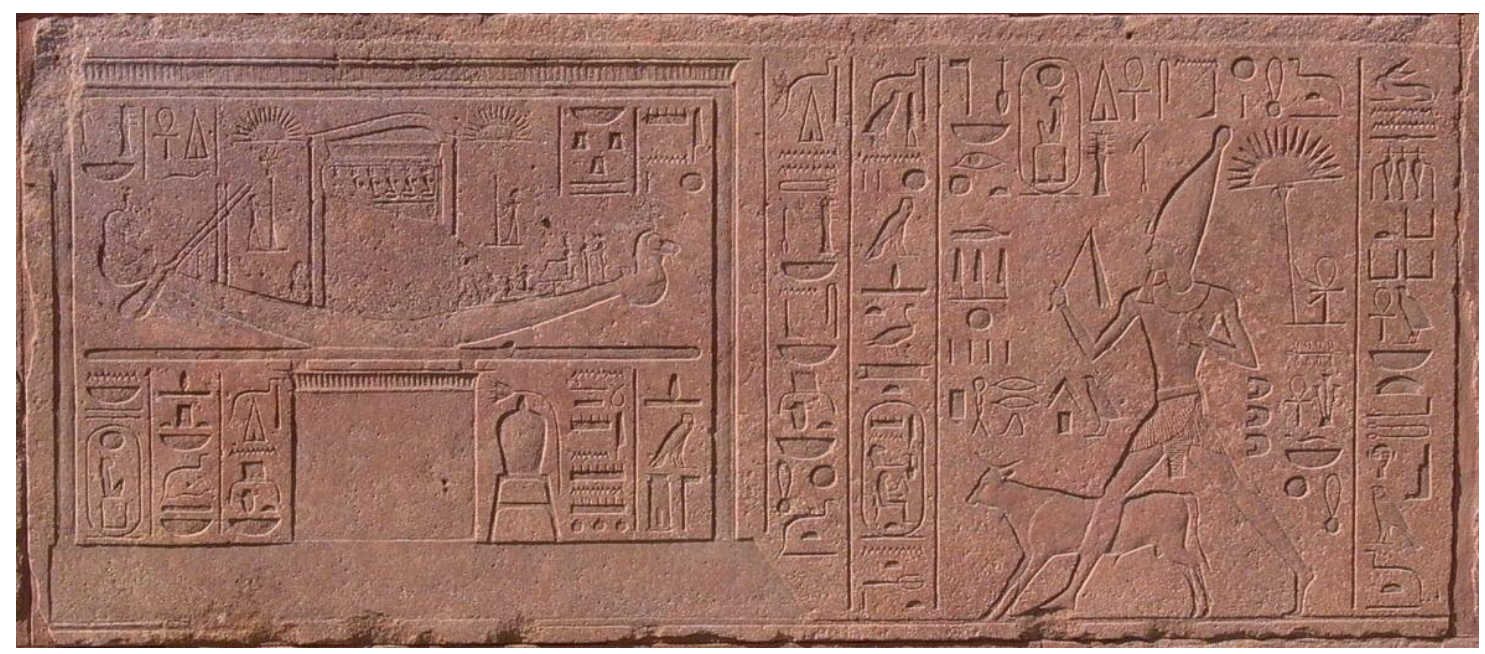

Figure 7: Queen Hatshepsut is running and accompanied by the Apis bull aside weser-h ${ }^{3} \mathrm{t}$ boat of god Amon, while resting on his own shrine, block no. 102, south wall, the red chapel at Karnak temple.

Source: Mironova, "The Relationship between Space and Scenery", 2010, Figure 6, p. 315. 


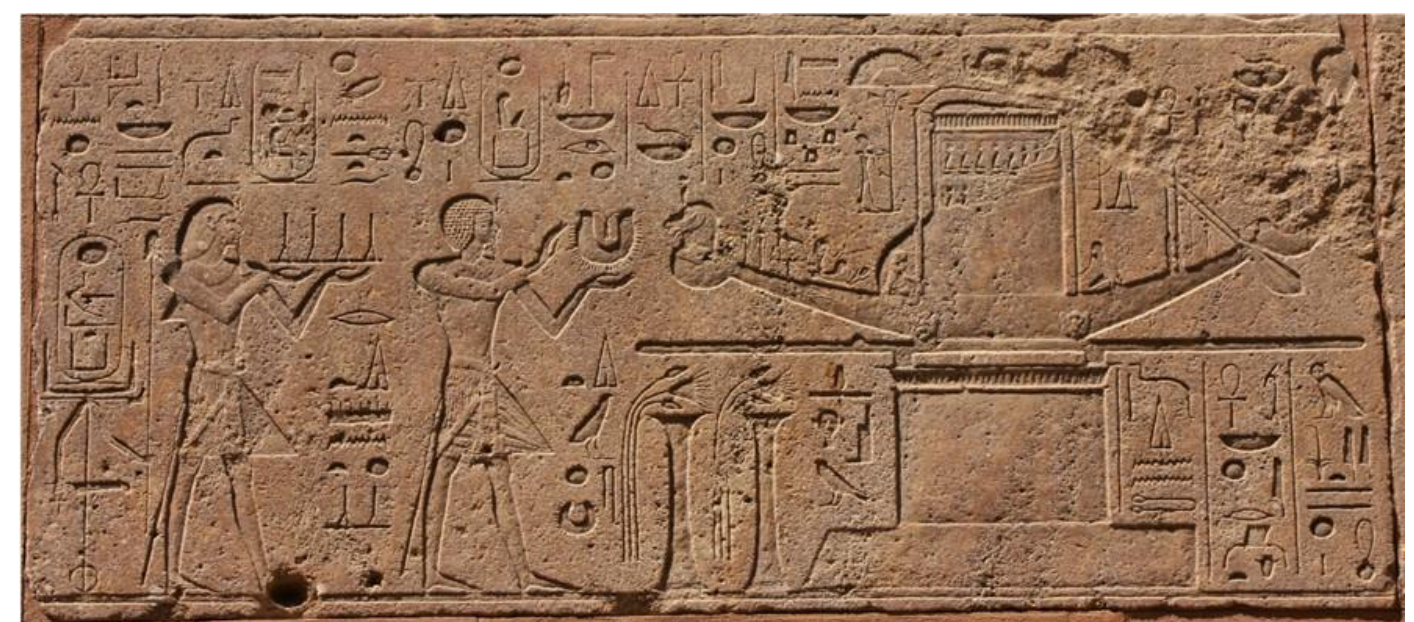

Figure 8: Queen Hatshepsut is presenting the wsh collar and the mnht cloth to the boat of god Amon, block no. 31 North wall, the Red Chapel at Karnak temple.

Source: Qumsan, M., "Amon Weserhat", 2020, Figure 33-5, p. 99.


Figure 9: The remaining parts of Amon's boat at Deir el-Bahari, the upper terrace, East wall.

Source: Naville, E., 1906, The temple of Deir el Bahari, V, London, pl. CXXVI.

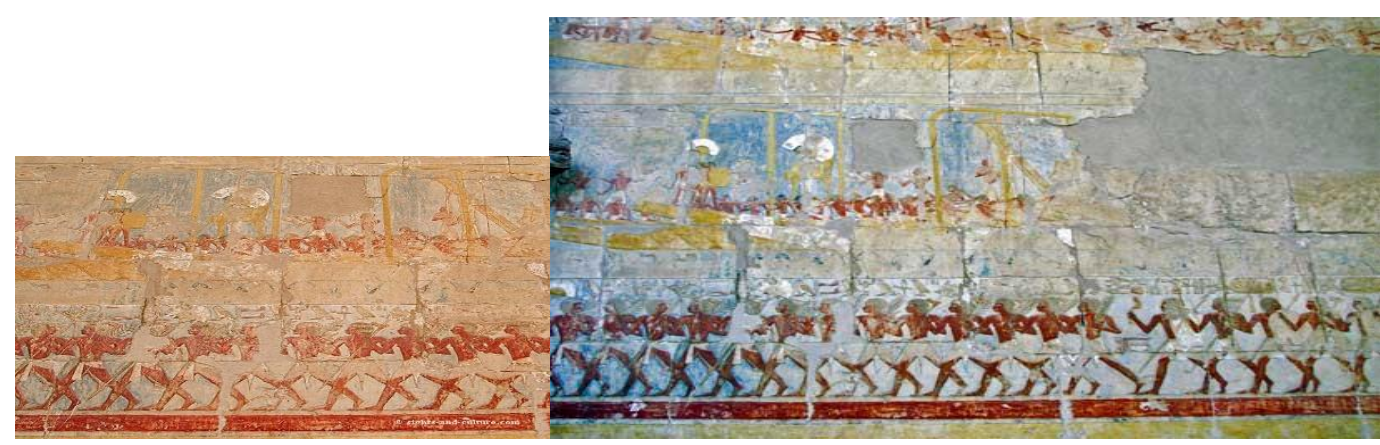

Figure 10: The running soldiers accompanied Amon's boat at Deir el-Bahari, the upper terrace, East wall.

Source: Pawlicki, F., 2017, The main Sanctuary of Amun-Re in the temple of Hatshepsut at Deir el-Bahari, Centre of Mediterranean Archaeology, University of Warsaw, p. 13. 


\section{Conclusion}

The Opet festival was such a religious festival which reconfirm the royal coronation, so most of the ancient Egyptian rulers who cared about the Opet festival ceremonies and representations, were those who had issues in their legal accession to the throne. Hatshepsut, Tuthmosis III and Amenhotep III were the best examples of these cases.

The scenes of the red chapel at Karnak temple depicted the Opet festival procession accompanied by the ruler, the priests, the dancers and musical bands (see figures 1-8). The same scenes at Deir El-Bahari represented the noblemen, rowers and soldiers (see figures 9,10). This could be based on the fact that the red chapel was such a ritualistic monument built in a cult temple, while the temple at Deir El-Bahary as a mortuary place was more commonly accessed. Additionally the upper terrace at Deir El-Bahary was working as a festival court wsht- hbyt , and was accessible by common people.

Regarding the investigated scenes, queen Hatshepsut in certain Opet festival scenes was presenting the wesekh collar to god Amon as a ritualistic performance (see figure 8). This was regarded as the first portrayals of the wsh collar as a protective gift presented to Amon in the Opet festival ceremonies, or as a decorative motif dressed on the ram's neck of Amon's boat edges.

The god $w p w^{3} w^{3} t$, the "opener of the roads", firstly appeared as a decorative motif on Amon's boat during Hatshepsut's reign at the red chapel at Karnak (see figures 6,7 ). This motif could be for facilitating and guarding the processional way of god Amon's boat.

Hatshepsut was commonly depicted together with Tuthmosis III during the performance of the Opet festival ritualistic ceremonies except her scenes inside the holy of holies, an issue which needs more investigation.

\section{Bibliographies}

Accetta, K., 2012, Access to the Divine in New Kingdom Egypt: Royal and Public Participation in the Opet Festival. In: C. Graves, et al. (eds) Current Research in Egyptology 2012: Proceedings of the Thirteenth Annual Symposium, p.1-21.

Barguet, P., 1962, Le temple d'Amon-Rê à Karnak: essai d'exégèse. Recherches d'archéologie, de philologie et d'histoire 21, Cairo, Institute Francais d'Arcchaeologie, p. 75-80.

Bell, L., 1985, Luxor Temple and the Cult of the Royal Ka, Journal of Near Eastern Studies 44 (4), p.251-294.

Bell, L., 1997, The New Kingdom "divine" temple: The example of Luxor. In Temples of ancient Egypt, ed. Byron Shafer. Ithaca: Cornell University Press, p. 127-184.

Cabrol, A., 1999, "Les Boeufs gras de la fête d'Opet: Remarques complémentaires sur des animaux d'exception", Cahiers de recherches de l'Institut de papyrologie et d'égyptologie de Lille 20, p. 15- 27.

Darnell, J.C., 1994, Two notes on marginal inscriptions at Medinet Habu. In Essays in Egyptology in honor of Hans Goedicke, ed. Betsy Bryan, and David Lorton, San Antonio: Van Siclen Books, p. 35 - 55. 
Darnell, J. C., 2010, Opet Festival. In: Jacco Dieleman, Willeke Wendrich (eds.), UCLA Encyclopedia of Egyptology, Los Angeles. http://digital2.library.ucla.edu/viewItem.do?ark=21198/zz0025n765, p.1-15.

Galán, J.M., et.al, 2010, Creativity and Innovation in the Reign of Hatshepsut, Studies in Ancient Oriental Civilization (SAOC) 69, p. 49-100.

Mironova, A.V., 2010, "The Relationship between the Space and the Scenery of an Egyptian Temple: Scenes of the Opet Festival and the Festival of Hathor at Karnak and Deir el-Bahari under Hatshepsut and Thutmose III", MOSAIK journal 1, 2010, p. 282.

Naville, E., 1906, The temple of Deir el Bahari, V, London.

Pawlicki, F., 2017, The main Sanctuary of Amun-Re in the temple of Hatshepsut at Deir el-Bahari, Centre of Mediterranean Archaeology, University of Warsaw.

Qumsan, M., 2020, "Amon Weserhat" The sacred Boat of God Amon in the Ancient Egyptian Sources. An Archaeological Study, An Unpublished Master Degree Thesis, Faculty of Arts, Asiut University.

Roehrig, C., et.al, 2005, Hatshepsut: From Queen to Pharaoh, The Metropolitan Museum of Art, New York Press, and Yale University of Art. 